JESÚS TEJADA

Universitat de València

TOMÁS THAYER MOREL

Universidad Metropolitana de Ciencias de la Educación

\title{
Design and validation of a
} music technology course for initial music teacher education based on the TPACK framework and the project-based learning \section{approach}

\section{KEYWORDS}

initial music teacher ICT training

\section{ABSTRACT}

This project outlines a design for, and presents an evaluation and validation of, an information and communication technology (ICT) training course on an initial teacher education programme for pre-service music teachers at a Spanish University. The primary objective was to improve initial teacher education in music technology through a course design with two key components: (1)
TPACK

project-based learning collaborative learning digital educational objects music technology 
constructivist learning through collaborative projects (PBL) and (2) the technological pedagogical content knowledge (TPACK) integration framework. The course saw students carry out four real-life projects, three of which involved the elaboration of educational material through the exclusive use of musical technology, and one of which involved an ICT research project. Results were obtained through an end-product evaluation and a self-assessment questionnaire and indicated that the course was well received and highly valued by the participants. In their self-assessment responses, students spoke of the academic value of the course, a confidence in their own skills, their willingness to use ICTs in future teaching contexts, the importance of ICTs in their degree programme, the fact that the course surpassed their expectations in terms of achievement (a fact corroborated through data triangulation in the end-product evaluation) and the transferability of the knowledge acquired to the music classroom. Finally, they provided suggestions for potential improvements to the course.

\section{INTRODUCTION}

Young people tend to overestimate their ability to read and evaluate online information, likely due to a positive self-perception associated with their expert use of social media and video games (Larson et al. 2018). Students enrolling in university, however, are not especially adept at reading and understanding complex online information. Indeed, they often find it difficult to assess the exactitude, reliability and bias of information online (Larson et al. 2018). This seems to refute the notion of digital natives (Prensky 2001) and has been confirmed by several studies (Ainley 2018; Helsper and Eynon 2010; Kirschner and De Bruyckere 2017). Secondly, initial teacher education curricula for primary school teachers tend to be heterogeneous in their approach to information and communication technologies (ICTs), with many universities now having removed general ICT training courses, such as those that existed before the Bologna Process and the creation of the European Higher Education Area (EHEA). The failure to include specific descriptors regarding ICT literacy, production and teaching allowed each university to decide whether ICT training should be present throughout a degree programme, or if it should have a specific place of its own in the curriculum (Aguaded-Gómez 2009). This could well have led to ICT education and teacher training being neglected, leading to problems when teachers are asked to apply ICT skills in the classroom. ICT training is important, but the way that training is carried out is even more so: ICT content must be interrelated with teaching content (Sweeney and Drummond 2013).

Several studies have highlighted the benefits of digital tools to learning processes in general (Dwyer and Larson 2014), and in secondary education (Lorenzo-Quiles et al. 2015; Pérez-Gil et al. 2016). Technology, in the context of teaching materials, has great potential for fostering learning in certain areas of experience in musical education, and can also occasionally act as an interdisciplinary mediator (Thayer et al. 2019). However, other studies have identified a certain degree of resistance from teachers in terms of their beliefs, attitudes, confidence, perceived competence in the use of technology in the classroom, curricular and organizational integration, and initial teacher training in ICTs (Boza et al. 2010; Crawford 2008; Haning 2016; Pérez-Escoda and Rodríguez-Conde 2016; Somekh 2008). 
There is plenty of literature regarding ICT training in initial teacher education. From it, we can identify a consensus regarding the mediating function of ICT training between the educational sciences and learning problems (Osborne and Hennessy 2003), but also a general agreement that the use of technology is not a panacea for all pedagogical issues (Himonides and Purves 2010).

One of the determining factors for a teacher's successful use of technology in the classroom relates to their beliefs, attitudes and confidence in their own competence and performance (Crawford 2008; Somekh 2008). These perceptions are formed mainly during a teacher's initial ICT training. In order to achieve the aforementioned success, ICT, disciplinary and pedagogical content must be interrelated; nevertheless, this does not always happen, and the preservice teacher fails to build their confidence (Haning 2016; Istenic et al. 2016). Likewise, the separation and compartmentalization of course contents in higher education leads to in-service teachers lacking the necessary confidence to properly apply ICTs in the classroom (Galanouli et al. 2004), meaning the use of ICTs in educational institutions is scarce (Dussel 2017).

This article is not founded on the myth of the essential goodness of technology; that is to say, the researchers do not believe that technology is intrinsically effective in the learning process. Instead, the study focuses on the processes of the use and learning of technology as part of a holistic, constructivist and interactive framework, with an understanding of the role a teacher must fulfil in an educational institution (Sancho et al. 2015). This is the premise that guided the design of 'Music and ICT', a course for the Universitat de València's taught undergraduate degree programme in primary education, majoring in music education.

The course design adopted a pedagogical model based on the following three elements. Firstly, we used five of the seven components of ICT literacy proposed by Mioduser et al. (2008) alongside Snow's (2004) general concept of literacy.

Secondly, we applied the concept of project-based learning (PBL) (Wilhelm et al. 2008). The projects in the course consisted of the collaborative design of teaching materials that would help music teachers in their daily professional practice; specifically, they focused on the teaching of musical instruments and the creation of musical arrangements. There are many studies that attest to the success of the PBL approach in terms of, for example, experiential reasoning and the understanding of relationships in infant education (Ljung-Djärf et al. 2014), improved results for students from disadvantaged socio-economic backgrounds in primary education (Halvorsen et al. 2012), significant gains in the understanding of contents and thinking skills in secondary education (Hernández-Ramos and De La Paz 2009) and notable improvements in scientific knowledge and argumentation skills in secondary education (Hsu et al. 2015). In higher education, academics have provided evidence to show the success of PBL in a range of disciplines: engineering (Fernandes et al. 2014; Hassan et al. 2008; Zancul et al. 2017), languages (Gibbes and Carson 2014) and teacher education (Ljung-Djärf et al. 2014; Mettas and Constantinou 2008). Although there is no absolute convergence of results in terms of the variables studied, the aforementioned research projects all agree that PBL provided substantial advantages when compared to the approach that had been used up to the time at which each study was conducted.

When it comes to music education, there are few scientific studies on PBL. Lasauskiene and Rauduvaite (2015) collected opinions and perceptions from teachers using PBL in initial teacher education classrooms for pre-service 
music teachers and found both positive and negative results in the categories of skill development in students, teacher-student collaboration, and professional development of teachers. Although they found that the function of PBL in music education is generally recognized, it appears to still be widely regarded as a periodic tool for innovation, indicating a need to see it implemented more systematically. The study also highlights that a lack of collaboration between the teacher and the students impedes the correct application of PBL, prevents the assumption of responsibility on the part of the students and reduces the likelihood of positive outcomes in achievements and learning. The researchers also mention that teachers frequently consider only the role of students in PBL and that their own competences are rarely considered. The 'absence of dialogue, or insufficient stimulation or reflection, can negatively predetermine the PBL experience' (2015: 791).

Thirdly, the projects designed on this course aim to interconnect disciplinary, pedagogical and technological contents, in a similar vein to the TPACK, or technological pedagogical and content knowledge model (Koehler et al. 2013); Mishra and Koehler 2006; Mishra et al. 2010; Thompson and Mishra 2007).

The course aims to serve as an opportunity for curricular integration, where pedagogical and disciplinary knowledge (i.e. music teaching, instrument and vocal instruction, rhythm training, music theory and audiation) merges with music technology. This way, multidimensional problems related to other subjects on the degree programme can be tackled through the elaboration of projects aimed at creating teaching materials for the primary education classroom, which will serve as both pretexts and contexts for meaningful learning among pre-service teachers.

TPACK helps provide a much more solid framework in initial teacher education than a generic technological literacy course (Figure 1). Technological knowledge (TK) encompasses all kinds of technologies, from lesser-known technological tools to digital media (Internet, digital video, digital audio, interactive whiteboards, etc.). Content knowledge (CK) covers all the material a teacher must know how to teach. Pedagogical knowledge (PK) refers to teaching methods and processes, including classroom management, evaluation and lesson planning. Pedagogical content knowledge (PCK) is related to the teaching process. PCK changes according to each area of knowledge and combines disciplinary and pedagogical content with a view to developing best practices for teaching in each area. Technological content knowledge (TCK) encompasses technologies that can be used for teaching in each discipline. TPACK is the knowledge required by a teacher if they are to incorporate ICTs into their teaching practice in any given content area.

It is necessary to mention here that the TPACK framework does not lay out or specify how this integration or interrelation should be carried out, but does recognize that there may be many ways of achieving it (Harris et al. 2009; Mishra et al. 2010; Mishra and Mehta 2017). This is the reason the results for TPACK are so irregular in terms of levels of achievement. A review of these levels and the validation of the construct can be found in Harris et al. (2017) and Herring et al. (2016). The empirical literature available on TPACK framework in music education is very scarce. Some works have described the possible applications of the TPACK framework in music education (Bauer 2014; Bauer and Mito 2017). Also, Bauer (2012) carried out a descriptive work based on surveys that investigated the relationship between music teachers' knowledge of TPACK and their level of technology integration in their classroom, finding a moderate positive correlation ( $r=0.51)$ between both variables (2012: 60). 


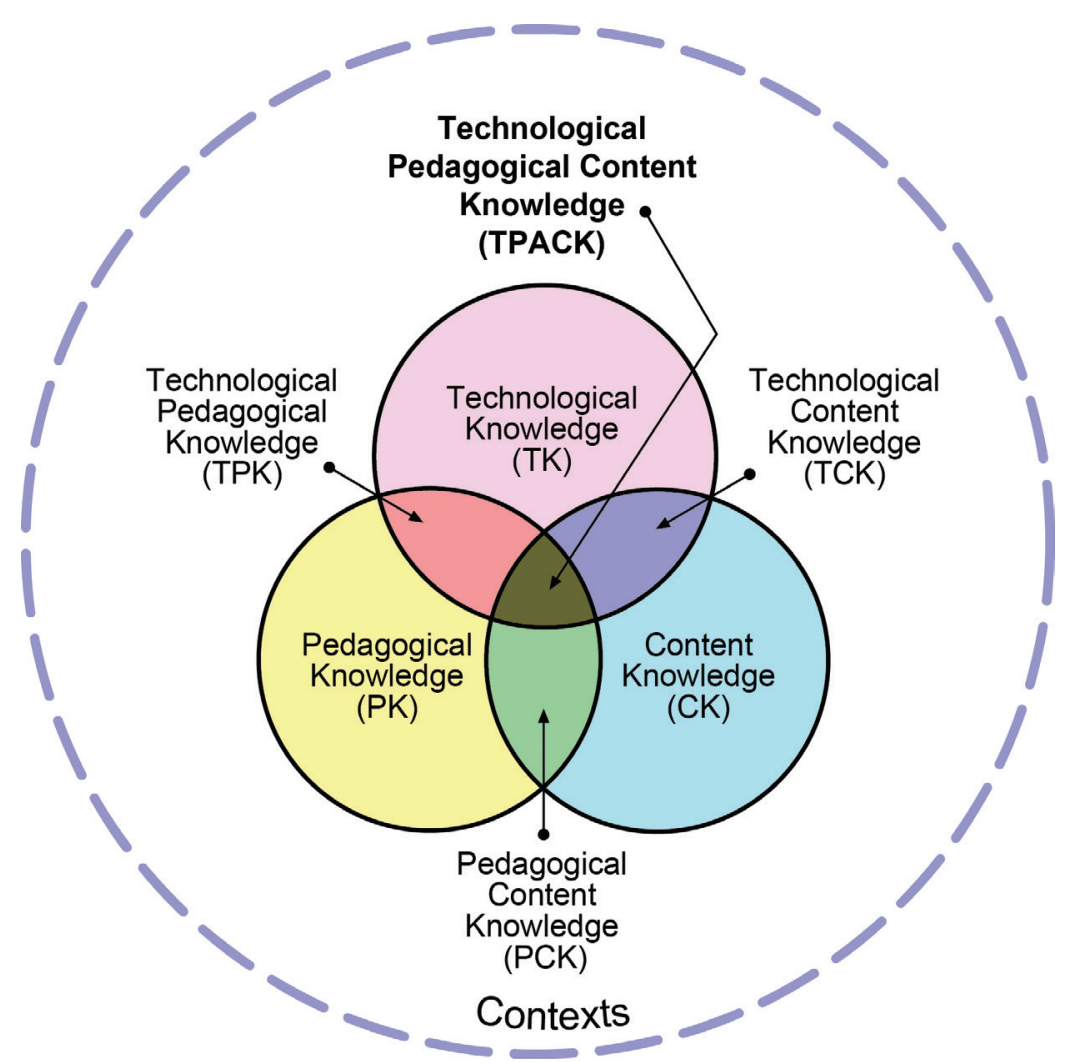

Figure 1: Components of the TPACK model. Reproduced by permission of the publisher, (C) 2012 by tpack.org.

\section{METHOD}

\section{Material design}

The course in this study was designed using an approach that interrelates disciplinary, pedagogical and technological knowledge in the form of projects aimed at creating teaching material for the primary education classroom, and whose function in music education is to mediate in the learning of an instrument and the creation of musical arrangements at school. The course was applied with two consecutive year groups (2017-18 and 2018-19) on the aforementioned degree programme.

\section{Technological literacy model}

Snow's six dimensions of literacy can be reduced to two poles, one of which can be defined as 'social, with the help of the community, culturally defined, varied and potentially transformative' (2004: 276-77). This definition was adopted as the theoretical basis for the course design. On top of this, we partially adopted Mioduser et al.'s (2008) proposal on technological literacy, which includes the following competences: 
- Processing information presented in a variety of forms, coordinating the skills and knowledge necessary to understand, produce and negotiate meaning in a culture composed of words, images and sounds.

- Successfully navigating information, which implies the combined skills of recognizing the need for information, finding it, codifying it, evaluating it, using it and communicating it ethically and efficiently.

- Ethically communicating information through a range of channels (text, images and audio) using a wide range of media (communication literacy).

- Decoding, evaluating, using or creating different types of image (static or dynamic) in order to facilitate the progress of thought, reasoning, decision making, communication and learning (visual literacy).

In the interrelated projects on this course, these skills are found in:

- The creation of classroom materials in the form of musical texts - scores - , their incorporation as MIDI files in ad hoc software, recording, importing and exporting audio, and sound or video sampling.

- Locating, managing, publishing and using musical scores, sound samples, song clips, sounds libraries or conceptual or procedural information for use in the projects.

- The use of information distribution and communication tools (Moodle, e-mail, chats) for the exchange of material used in the projects and for communication with peers and with the teacher.

- The design and recording of videos for instrument instruction, including the application of audio-visual language.

\section{The interrelation of learning contents}

Figure 2 shows how disciplinary, technological and pedagogical contents are integrated in each project.

Some of the musical content necessary for the elaboration of projects or for their execution are (1) the fundamentals of harmonization and (2) the foundations of arrangements for school musical pieces.

The technological content of the projects includes the following: (1) the graphic interface and functions of score editing software. (2) The graphic interface and functions of a multitrack recording software; recording hardware; connections, digital audio channelling and routing; post-production; (3) recording and editing MIDI data. VSTi software. Channelling and routing MIDI data. Rendering and mixing; (4) the graphic interface and functions of video editing software. Video capture and edition. Formats. Rendering and (5) the recovery and use of digital information.

Some pedagogical content pertaining to music education was also implemented in order to help the students find common ground between the types of content and design music education activities using technology as a facilitator (Leman and Nijs 2016) in the kinds of classroom where they will work professionally. The pedagogical contents covered in the four projects are: (1) teaching idiophones and lesser percussion instruments: methods of percussion, acoustics with sticks and mallets made of different materials; (2) sequencing the use of the material created in the projects for application in future teaching practices and (3) methodologies for musical instrument instruction with primary education students. 


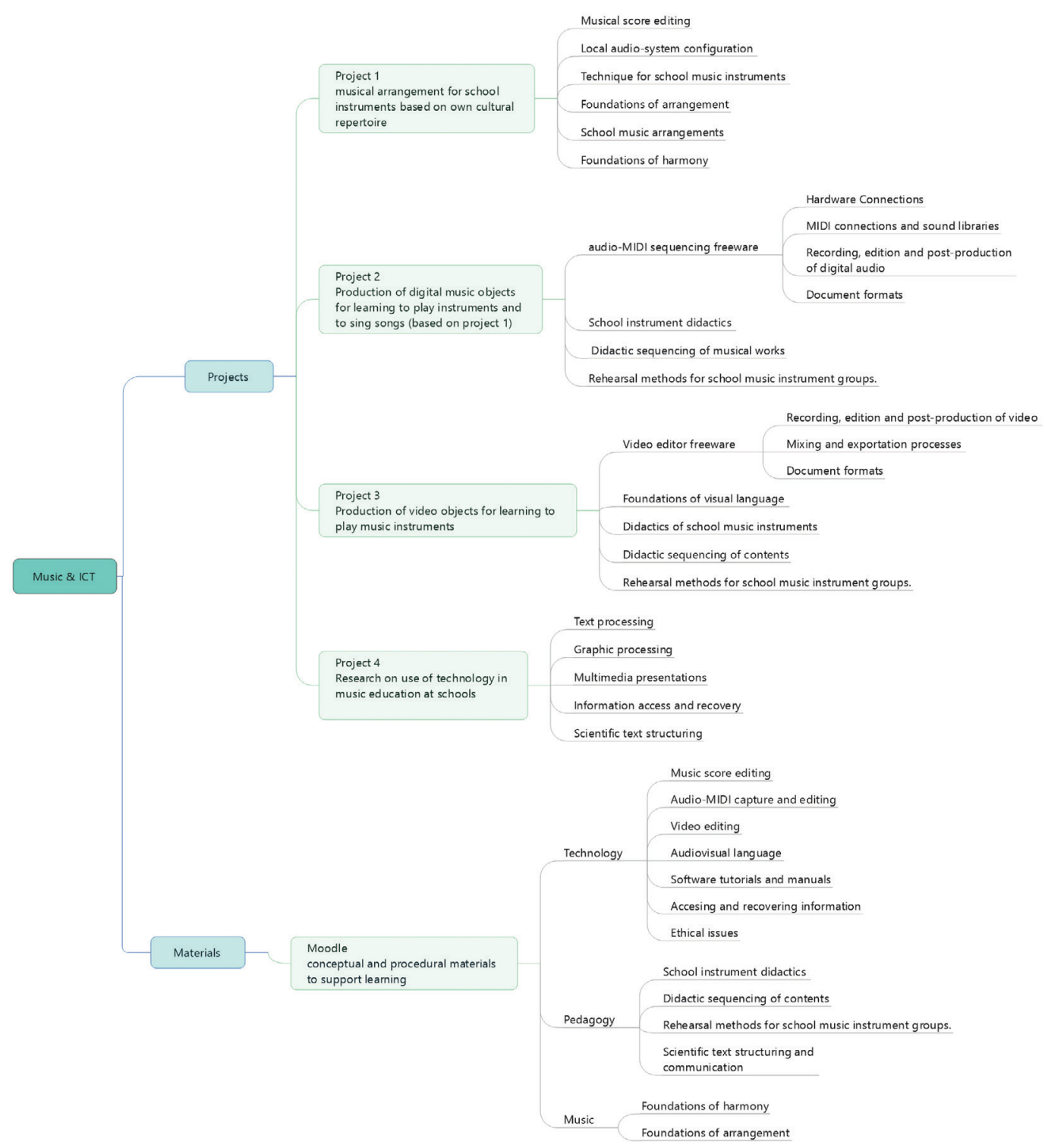

Figure 2: Project breakdowns, contents and support materials.

\section{Project-based learning}

Student-centred approaches define the concept of learning as an interaction between affective, cognitive, social and communicative factors. PBL brings all these factors together in one strategy. It requires a shift from the concept of the class as a lecture and individual learning experience to a participative model that organizes learning around projects that are cantered on the students and their interactions with their peers and teacher in order to establish a zone of proximal development (Vygotsky 1979). The projects include complex tasks that involve the students in project design, problem-solving, decision-making 
or research activities, and culminate in real end products (Kokotsaki et al. 2016). This means the students are obliged to study real, meaningful problems that are important to them and helps them improve their creativity and problem-solving skills (Lee et al. 2014). PBL is characterized by its generation of an end product: a concrete artefact that represents the students' understanding, knowledge and attitudes in relation to the topic being researched. In Figure 2 , we can see a layout of the projects, their end products, the content associated with each one and the types of support materials involved. The following section describes the projects undertaken during the course.

\section{Project 1: Creating an arrangement for school instruments}

This project consisted of the selection of a melody followed by the creation of an arrangement of four or more instruments using an open-source music score editing software. The project was suggested by Gilbert (2016) as an 'activity' for a student-centred classroom. It is related to the other two projects that make up the students' portfolio, in which they had to record and play the arrangement (Project 2) and record individual videos for each part (Project 3). For conceptual support, students had access to materials on the Moodle platform for the projects on the course.

The content covered in the activities was (1) disciplinary (the fundamentals of harmony, rhythmic complementarity, the creation of accompaniments); (2) technological (the software's graphic interface, audio in and out, the creation of musical scores, MIDI exports) and (3) pedagogical (instrumental instruction in a school group: avoiding problems in the arrangements such as those that arise from the concrete skills of primary education students, such as simultaneous hand movements - that are not parallel - , the interpretation of fast rhythmic values, patterns that are impossible to memorize due to length or asymmetry). The end product was a printed sheet containing the arrangement for school instruments, which was to be played and recorded in Project 2.

\section{Project 2: A multitrack recording of a musical arrangement}

This project consisted of recording the instrumental parts of the arrangement composed in Project 1 using a desk audio workstation (DAW) software and microphones. Besides recording with school instruments, each group was free to generate MIDI data and activate them with sounds from digital sound banks. The support materials available on Moodle include a video demonstration of the software's main functions. The content covered in the activities was (1) technological (interconnecting recording hardware, optimizing the elements necessary for recording, achieving the best signal-to-noise ratio, executing the basic operations of the software including creating and configuring tracks, editing audio, controlling dynamics and sound balance, using equalizers, adding audio effects, re-channelling audio and MIDI, and mixing); (2) disciplinary (the creation of intros and codas, controlling harmonic density and rhythmic saturation) and (3) pedagogical (didactic sequencing of the material to be created and the music ensemble methodology). This way, students would understand the logic of both the didactic material they were creating and the steps they would have to follow in a hypothetical classroom situation. The end product was a set of audio playback files including the arrangement played on school instruments found in the primary education classroom, which would be complemented by the video files created in Project 3. 
Project 3: Video recordings of the parts of the arrangement

This project involved the recording of a video of each of the individual parts in the arrangement of instruments or vocals from Project 2. In practice, the students recorded each part on their cell phones and edited the videos using an open-source video recording and editing software. The project was executed in parallel with Project 2. Examples of some of the activities in this project included recording takes from different angles, designing the video presentation in line with the maximum length of each instrumental part (and the students' attention spans), inserting transitions, titles and effects, and the creation of a multi-camera video. The end product was a set of individual videos that provided a visual and audio aid for each of the parts in the arrangement. The videos were to be able to be used either individually or in conjunction. The point of the material produced in this project was that the teacher could use the videos before the audio tracks, allowing the primary education students the chance to get to know each instrumental part beforehand. In a real-life classroom situation, once the part has been learned with the help of the video, the files from Project 2 can be used as a backing track for students to play each part over.

\section{Project 4: Research into music technology in primary education}

This project involved a descriptive-investigative study, either of document analysis or applied teaching theory, regarding the use of ICTs in music education. Despite being apparently unrelated to the other projects on the course, the objective of this project was to add an element of theoretical reflection regarding technology-assisted learning and to develop some of the competences related to technological literacy proposed by Mioduser et al. (2008), mentioned above. Some of the proposed topics for study were as follows: (1) concrete aspects of the use of ICTs in the classroom (best practices for ICTs in music education, a critical analysis of the use of ICTs in the classroom, a case study of teachers who use ICTs in the classroom, designing didactic strategies for music education using ICTs); and (2) up-to-date software or hardware that are appropriate for use in the classroom (a critical analysis).

\section{Evaluation}

\section{Participants}

The participants were the 2017-18 and 2018-19 year groups ( $n=46)$ studying for an undergraduate degree in primary education, majoring in musical education, at the Universitat de València. The course was worth 4.5 ECTS credits and was imparted in two 1.5-hour sessions per week, with a significant amount of autonomous worked assigned to the students.

\section{Data collection techniques and instruments}

The data collection techniques and instruments used in this study were as follows: (1) independent rubrics to provide a quantitative evaluation of the end products of each of the four projects. (2) An end-of-course questionnaire with three key questions to evaluate the pre-service teachers' attitudes towards music technology in the primary education classroom. (3) A second questionnaire with open-ended questions regarding the students' perceptions of the course. The data collected were broken down for analysis, grouped together under a number of codes and then into five categories (see below). 


\section{RESULTS}

\section{End-product evaluation}

Each end product was evaluated using an independent rubric. For example, the rubric for Project 2 - multitrack recording - contained the following criteria: (1) well-intonated performance with instrument or voice; (2) rhythmic synchronization between the parts; (3) expression of the lead instrument or voice (agogics, phrasing, dynamics, articulation); (4) adaptation to the minimum time given for the project; (5) use of sound balance, effects and equalization; (6) use of MIDI tracks; (7) adequation of the tempo of the piece to the skills of children; and (8) adequation of the playbacks created for rehearsing each part of the arrangement. The average grades for each of the projects were relatively high in each year group (Figure 3 ), whereas the overall average of all four projects was somewhat higher in the 2018-19 group $(M=7.88)$ than in the 2017-18 group $(M=7.37)$.

\section{Student perceptions}

Student perceptions were collected using two separate instruments: a priorexperience questionnaire (including three questions related to the students attitudes towards technology) and an end-of-course evaluation questionnaire.

\section{End-of-course evaluation questionnaire}

The information collected in this questionnaire included (1) age; (2) type of primary and secondary school attended; (3) opinions on the music education received at those schools; (4) prior experience in music before enrolling on the degree programme; (5) familiarity with different kinds of software; (6) familiarity with musical hardware; (7) the kinds of tasks undertaken with different kinds of musical hardware; (8) social media use; (9) the question

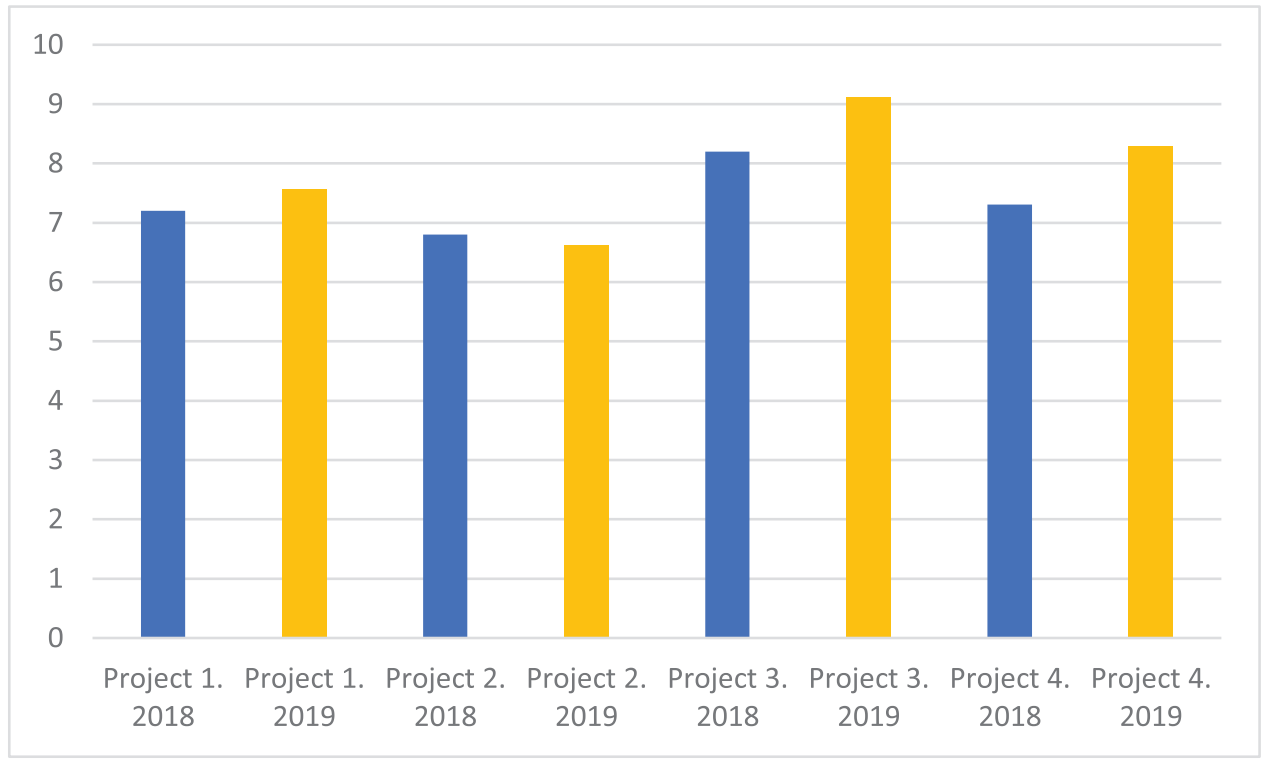

Figure 3: Average grades for each project for year groups 2017-18 and 2018-19. 


\begin{tabular}{lcc}
\hline & Frequency & $\mathbf{\%}$ \\
\hline No & 9 & 19.6 \\
Yes & 37 & 80.4 \\
Total & 46 & 100.0 \\
\hline
\end{tabular}

Table 1: End-of-course questionnaire answers regarding pre-service teachers' selfperception of their ability to use music technology in their future careers.

\begin{tabular}{lcc}
\hline & Frequency & \% \\
\hline No & 3 & 6.5 \\
Yes & 43 & 93.5 \\
Total & 46 & 100.0 \\
\hline
\end{tabular}

Table 2: End-of-course questionnaire answers regarding the willingness to use music technology to create music in classes.

'[d]o you believe you will be able to use software and music technology equipment in your future career as a teacher?' (Table 1); (10) the question '[w] ould you use a range of digital tools, such as sequencers, digital recording systems, auditive trainers and sound editors to make music in your classes?' (Table 2); (11) an open question asking for the reasons behind their previous answer. Forty-six students from both year groups filled out the questionnaire. The final three questions were the most relevant to this article (the other data have been omitted).

The final question - the reasons why students would or would not use technology as a means to create music in the classroom - was qualitative. Positive answers were codified and then placed into one of four categories according to their content: student-related advantages, teacher-related advantages, social or contextual advantages and advantages related to available resources.

\section{Open-ended course evaluation questionnaire}

Each participant filled out an open-ended self-assessment to evaluate the course. A number of guidelines were provided regarding the aspects to be evaluated:

- Provide your opinions regarding the course: usefulness, adequacy or any other ideas you would like to mention.

- What do you feel that you have or haven't learned?

- What did you expect from this course? What has or hasn't been achieved?

- What other perceptions do you have regarding projects, teamwork, organization, infrastructure, assessments, repertoire, difficulties, logistics, autonomous work, etc.?

- What score (on a scale of 1 to 10) would you give yourself for your participation on the course, taking into account your attendance and dedication?

The answers to these suggestions were codified and grouped into five categories based on the information they contained (Figure 5). Some categories were pre-established, based on the suggested evaluation criteria, while 


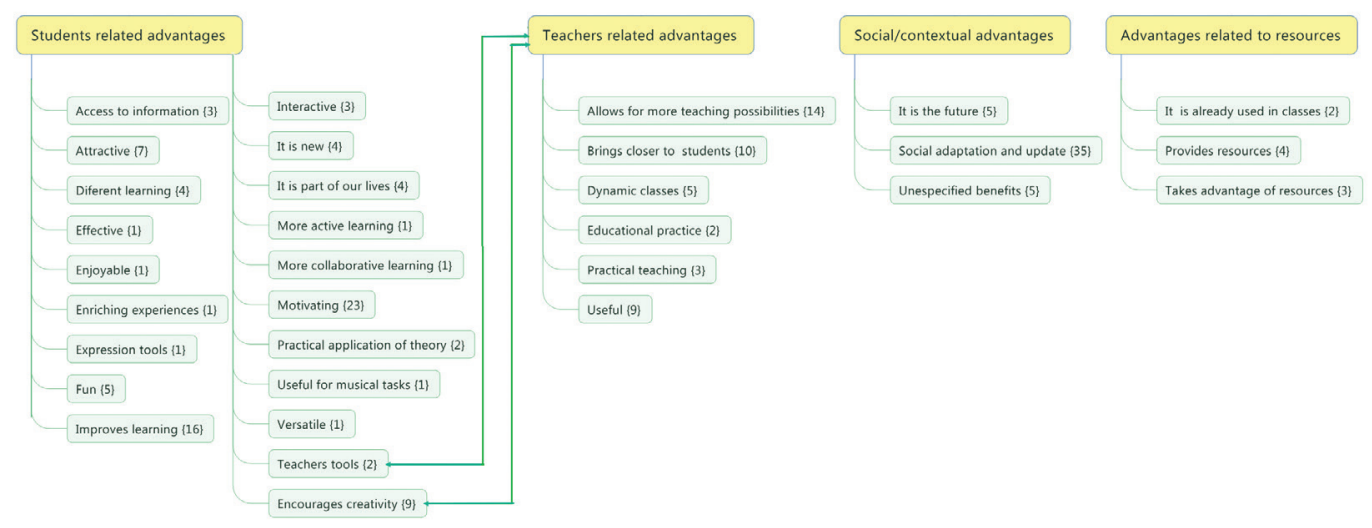

Figure 4: Semantic network showing the reasons specified by students for using technological tools to make music in class (frequency of units of analysis is between curly brackets).

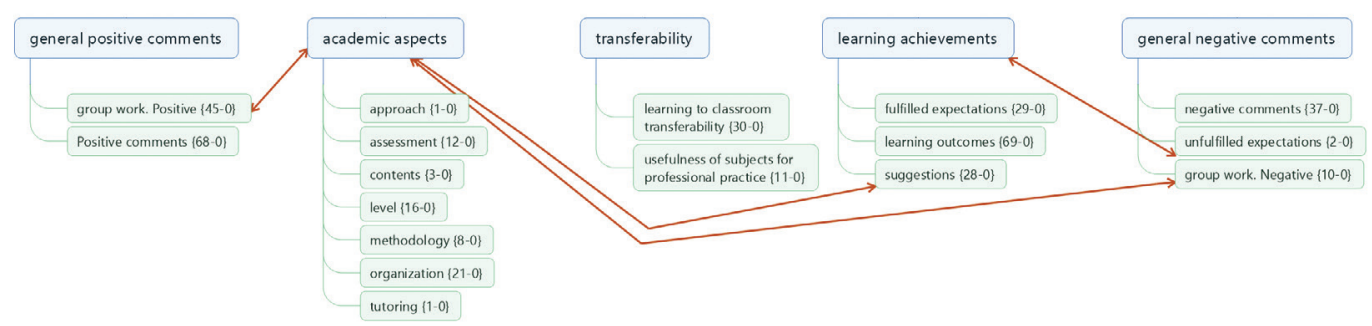

Figure 5: Analysis categories and codes arising from student self-assessment from both year groups (frequency of units of analysis is between curly brackets).

others arose from the answers themselves and our analysis of them: (1) general positive comments, (2) academic aspects, (3) transferability, (4) learning outcomes and (5) general negative comments.

\section{General positive comments}

The 2018-19 year group provided more general positive comments than the 2017-18 year group. In their comments, students highlighted the integration of contents, collaborative work, technological literacy, usefulness, the improvement of skills, a broadening of their methodological knowledge and the effectiveness of technology as a pedagogical tool. They note that the course was 'useful', 'enjoyable', 'positive', 'important' and 'necessary' in initial music teacher education. Likewise, it is worth noting that many students spoke of fulfilled expectations ( 29 units), which is analysed below in the learning outcomes category.

\section{Academic aspects}

The academic aspects of the course were very well evaluated by the students. In terms of the focus of the course, one student mentioned that it was very appropriate; we studied the usefulness of ICTs as teaching tools and then went on to use them in the classroom' (14:34). 
Regarding the difficulty of the content, there was a range of opinions, although the majority noted that the level was appropriate for the group as a whole, using terms such as 'accessible', 'appropriate', 'intermediate level', 'technical level' and 'a not too demanding level'. Some students rated Project 2 (audio and MIDI recordings) as more difficult than the other projects. In this regard, one student, despite finding Project 2 both complex and difficult, stated that'it was a challenge [...] which was welcome. At times I felt that the other tasks were a little simple or structured, and that they didn't allow for the cognitive dissonance that leads to learning' (14:43).

Regarding the organization of the course, most students said that the planning and scheduling of the course were adequate and in line with the outline presented at the beginning. This included a concept map with objectives, contents, activities, projects, assessments, scheduling and the application of autonomous work. Student 9 remarked: 'since day one we knew exactly what we were expected to do, with hand-in dates and the number of classes dedicated to each project. And we stuck to that schedule' (14:37). The students also pointed out that the course 'was well organized' (14:13) and that the time assigned to each project 'was sufficient' (13:139; 13:207; 14:37).

The group work aspect was rated highly by both year groups, with many more positive units of analysis (68) than negative ones (8). In general, students talked about the enriching aspect of collaborative work and the exchange of opinions, mutual learning experiences, the sense of satisfaction and the adequate focus of the course on group work. The negative opinions regarding group work (ten units) mostly cantered on the roles played by different group members, the lack of interest or commitment of the members (or their 'willingness to work'), the strained interpersonal relationships in some groups and, as a result, the unfair distribution of workloads.

Opinions regarding the content were scarce (three units) but were all positive. The students found the contents to be 'adequate' (13:118), 'accurate' (13:74) or'useful' (13:102).

All of the units of analysis related to the course methodology were positive: '(the methodology) was very meaningful' (14:23); 'it helped us reflect' (14:40); 'it was correct' (14:152); 'I think it was well executed as it encouraged group work' (14:143); 'we learned as we worked' (14:111) and 'working from easier to harder content was key to learning' (14:187). One student thought that the tutoring was excellent (14:96).

The assessment system was mentioned in twelve units of analysis, and all of them were positive. Students used phrases such as 'I thought the assessment was fair' (13:55); 'the criteria were well explained' (13:110); 'using the projects for assessment [...] increases the value of the time we spent on them' (13:140); 'the weight [of each project] was in line with their difficulty, and I think that is fair' (14:38); 'everything was adequate' (14:25); 'it was fair' (14:65); 'the assessment was a positive aspect' (14:89); 'it was well executed' (14:97) and 'the assessments seemed coherent' (14:114).

\section{Transferability}

Transferability was mentioned in two codes: transferability of knowledge to the classroom and the usefulness of the course content. Thirty units of analysis came under the first of the codes, and all were either positive or very positive, stating that: what the students learned could be implemented in their future classes and make them less monotonous (13:13), the projects are excellent 
tools for improving and strengthening learning in the music classroom (14:14) and one of the best aspects was actually seeing how the content could be applied rather than learning about vague ideas regarding the introduction of ICTs into the classroom (14:20).

The contribution of the subject to the degree programme code was mentioned in eleven units of analysis, wherein the unanimous opinion was that the course was'very useful'.

\section{Learning achievements}

The analysis category of learning achievements has four codes: learning outcomes, fulfilled expectations, unfulfilled expectations and suggestions. Of the 68 units of analysis that came under learning outcomes, many students openly stated that they had almost no technological abilities before beginning the course, that they felt stressed about having to take the course and worried about not taking advantage of it or that they were worried about the potential level of the content $(13: 141 ; 14: 33 ; 14: 138)$. Likewise, the students stated that, having taken the course, they had learned to use digital tools to aid the teaching of music (13:97), that they had done things they had never thought possible (such as the production and post-production of audio and video material of their own interpretations) and that they had enjoyed the projects (13:104; 14:146).

The use of score editing software is most common among the students (13:127), but they stated that the real learning outcome of using this kind of software in a course with integrated contents was applying it to the creation of musical arrangements for school instruments, which they had not dared to try before, mostly due to a lack of integrated knowledge (13:112). Similarly, Project 4 helped students develop a critical view of ICTs in the classroom (14:39), as they were free to explore a range of topics and approaches regarding the use of technology in the music classroom and to present their findings to their peers $(13: 175 ; 13: 212)$; 'having to research something on our own and to present the findings to our classmates obliged us to do some deep investigation [...] to gather plenty of information [...] and we learned a $\operatorname{lot}^{\prime}(14: 88)$.

Perhaps the most important learning outcome highlighted by the students was their realizing that 'we really can teach music with applications, platforms and programs, and that these resources are both good and accessible' (13:150), or that' choosing a song, creating an arrangement, recording an audio or video [...] are great tools to apply in the future' (13:169).

In the 29 units of analysis under the fulfilled expectations code, students stated that they had no concrete expectations for the learning outcomes of the course $(13: 16 ; 13: 172 ; 14: 63$, etc.), that they thought the course would be more theoretical (13:37), or more complex (13:124), or that they weren't surprised by the results obtained $(13: 59 ; 13: 64 ; 13: 78$, etc.). The following is a statement that sums up a general feeling in this regard:

I think the course was essentially what I expected it to be; that is to say, we worked on some music projects, we went one step further in terms of editing, and we have learned to use new resources and have more options to apply in our future as teachers or musicians. It has given us, at least in my opinion, better skills and more flexibility when it comes to preparing musical arrangements. We should now have no qualms about working with new technologies and seeing the benefits they have on learning. 
In general, the course results surpassed the students' expectations (13:196; 13:200; 14:45; 14:56, 14:98; 14:159, etc.). The unfulfilled expectations (two units) were related to inconsistencies between the expected content and the actual content (13:106), although the student who made this observation admits that there was a limited timeframe and that it would have been impossible to cover everything. Another student mentioned that they expected to receive more structured guidance in the use of the software (13:135).

The suggestions code has 28 units of analysis that can be summarized as follows: using a simpler sequencer so as not to depend on the university facilities and to allow for working from home (13:31; 14:149); making time to explore other software and find more digital tools $(13: 93 ; 13: 98 ; 13: 136$; 13:181); learning to critique these tools (13:98); studying the musical content in more detail (13:132); using software designed for primary education (13:180; 13:188); having a teacher available who can show the software in use in a classroom context (13:189); working on things other than the projects (14:7; 14:54); allowing more time for Project 4 (14:10) or for working on other things, or leaving more time for recording (14:52; 14:102; 14:103), which was also a point raised in the negative comments; showing the recorded arrangements (Project 2) to the whole group to learn from mistakes and see other ways of approaching the task (14:53); working on the arrangement in a real classroom with children (14:55). Most of the suggestions were provided by the 2017-18 year group, and some of them were implemented for the following year. Of course, many of the suggestions are the same as or similar to the negative comments, which are detailed below.

\section{Negative comments}

This category includes the codes generally negative comments (37 units); negative comments about group work (ten units), which were described in academic aspects and unfulfilled expectations (two units), which were detailed in the previous section learning achievements. One student complained that the level of the course was not 'advanced enough' (13:3) whilst others state the opposite (13:79). Several comments alluded to the difficulty of the recording software (13:5; 13:35; 13:103; 13:178; 14:116), which led to them spending an excessive amount of time on the recordings (13:56). Students commented that they found the course to be very important, but lacking sufficient time $(13: 105 ; 13: 174$; 13:186; 14:29), which leads to the feeling of not having gone deep enough into the uses of the technology $(13: 7 ; 14: 116 ; 14: 122)$. Some comments stated that too much time was spent on 'easy' software (meaning Musescore) (13:15; 13:204). Two students complained about having to work with harmonic exercises in the score editing software in order to simultaneously cover technological and musical content (harmony, arrangement), because they believed their prior level of musical ability was insufficient (13:17; 13:79). Comments were also made about the technical problems during recording (13:49; 13:50; 13:184; $13: 185 ; 13: 214 ; 14: 123)$. There was apparently a problem with coordinating groups to record Project 2 in the designated classrooms (13:53). One student mentioned a desire for the course to focus on technology as a tool for students rather than as a tool for teachers to create classroom material (13:60). Finally, two students mentioned that the projects took up time outside of class (autonomous work), which led to some issues with timetable compatibility among students and clashes with their extracurricular activities (13:145; 14:142). 


\section{DISCUSSION AND CONCLUSIONS}

The qualitative and quantitative data obtained in this study have highlighted positive attitude results that are consistent with the existing literature on PBL in music education (Lasauskiene and Rauduvaite 2015) and in other disciplines where the strategy has been employed (Fernandes et al. 2014; Gibbes and Carson 2014; Hassan et al. 2008; Ljung-Djärf et al. 2014; Mettas and Constantinou 2008; Zancul et al. 2017). The lack of research on TPACK in music education and the descriptive-exploratory nature of this study mean the results shown here should be treated with caution when being compared to those of studies in other areas.

The results show that the students generally considered the course to be well designed. The quantitative evaluation produced excellent results, with the average grade rising for the second year group (7.88) when compared with the first (7.37). The students' perceptions of the course were also very positive on the whole in all of the categories analysed, as discussed in Section 3.2 of this article. There were many general positive comments in general, and more in the second year group. Both the academic aspects and the transferability of the course were highly rated. In terms of learning outcomes, the students were very descriptive and positive when commenting on the results of the course. There were around half the number of units of analysis in the general negative comments category as in the positive comments category. The data obtained from the attitude-related items on the end-of-course questionnaire showed that 80 per cent of the students will use music technology as a teacher and that 93 per cent will use it to make music in the classroom (Tables 1 and 2), which seems to confirm the students' self-confidence regarding their ability to use technology in a teaching situation.

In a similar way to the suggestions, the negative comments collected - half the number of the positive comments - were more common in the 201718 year group than in the 2018-19 group. One possible explanation for this result is that several of the suggestions and negative comments of the first year group were acted on before the second year group began the course. For example, the amount of time spent working with each software was modified, as was the amount of time assigned to projects (autonomous work); attempts were made to reduce the technical issues encountered through extensive equipment maintenance and monitoring, although many issues were down to student inexperience in basic operations, the idiosyncrasies of the graphic interface of the sequencing programme or the use of the audio interface; finally, we tried to reduce the impact of the knowledge of music theory in Project 1 with more intensive teacher-researcher tutoring. Some of the negative comments in the group work code are found in other PBL studies in higher education, such as the unequal distribution of workloads and responsibilities (Gibbes and Carson 2014). This may be due to varying levels of student motivation given their different career goals: some people with professional training or higher education in music enrol on this degree programme to have a 'fallback' career option, while others with less training in music feel a natural vocation for teaching. The first group are less motivated than the second, as they are aiming to become professional musicians. Teaching would be a secondary option for them.

It is also worth noting that there were a few problems with prior knowledge in both musical and teaching terms. For example, some students were lacking in instrument-playing ability or in knowledge of sequences and methodology 
for teaching instruments in groups. This is a potential weakness in the viability of the TPACK-PBL design. The lack of emphasis on playing ability in the entry test for the degree programme could cause problems for some students when it comes to tackling the material in the projects. Furthermore, this music and ICT course comes in third year, before the musical didactics course in fourth year. This means that some pedagogical content is necessarily brought forward and that the teacher must be an expert in three fields, which is largely uncommon in music teaching.

A suggestion for overcoming this problem would be to break up the technological content of this course into modules and have them taught in other music education subjects (rhythmic training and dance, ear training, vocal training, instrument training and musical didactics), wherein the technology to be studied is adapted to the specifics of each course. All of this, of course, should be in line with TCK and PBL. The teaching responsibilities in such cases should be shared. Likewise, in order to avoid the problem of the lack of basic playing skills, the music and ICT course should be taken during the final year of the programme, after all the mandatory courses covering music education. This would increase its effectiveness as a space for the creation of teaching materials under the TPACK framework and PBL strategy. This would reduce the issues of knowledge gaps in music, teaching and even technology.

It would be advantageous to replicate this course in other contexts of initial music teacher training. It would also be a good idea to refine the TPACK design in order to allow for the construction of pedagogical reasoning and to apply this model systematically in initial music teacher training.

Finally, we would be interested in redesigning the course to take into account one of the more pertinent suggestions provided by students: that the focus should not be exclusively on using technology for teaching, but also on using technology for encouraging primary school students to think about music and learn autonomously through technology.

\section{ACKNOWLEDGEMENTS}

This research project was co-funded by the Chilean Ministry of Education (Institutional Improvement Plan), Universidad Metropolitana de Ciencias de la Educación (code PMI-EXA/PNII/05/2017, 'ICTs in the curriculum; research into educational standards for improving digital skills, and the integration of these standards into initial music teacher training programs') and the Spanish Ministerio de Ciencia e Innovación (code PID2019-105762GB-I00). We would also like to thank Edwin Abbett, who translated this article into English from the original Spanish.

\section{REFERENCES}

Aguaded-Gómez, I. (2009), ‘Miopía en los nuevos planes de formación de maestros en España ¿docentes analógicos o digitales?' ('Short-sightedness in initial teacher education curricular in Spain, analogue or digital teachers?'), Comunicar, 17:33, pp. 7-8.

Ainley, J. (2018), 'Students and their computer literacy: Evidence and curriculum implications', in J. Voogt, G. Knezek, R. Christensen and L. KwokWing (eds), Second Handbook of Information Technology in Primary and Secondary Education, Cham: Springer International Publishing, pp. 70-88.

Bauer, W. I. (2012), 'The acquisition of musical technological pedagogical and content knowledge', Journal of Music Teacher Education, 22:2, pp. 51-64. 
Bauer, W. I. (2014), Music Learning Today: Digital Pedagogy for Creating, Performing, and Responding to Music, New York: Oxford University Press.

Bauer, W. I. and Mito, H. (2017), 'ICT in music education', in A. King, E. Himonides and A. Ruthmann (eds), The Routledge Companion to Music Technology and Education, London: Routledge.

Boza, A., Tirado, R. and Guzmán-Franco, M. (2010), 'Creencias del profesorado sobre el significado de la tecnología en la enseñanza: Influencia para su inserción en los centros docentes andaluces' ('Teachers' beliefs regarding the meaning of technology in teaching: Support for its insertion in educational institutions in Andalucía'), RELIEVE, 16:1, pp. 1-24.

Crawford, R. (2008), 'Are resources solely to be blamed? The current situation on music education facilities, computer and music technology resources in Victoria', Australian Journal of Music Education, 1, pp. 44-55.

Dussel, I. (2017), 'Perspectivas, tensiones y límites en la evaluación de las políticas Uno a Uno en América Latina' ('Perspectives, tensions and limits in the evaluation of One-to-One policies in Latin America'), in S. B. Larghi and R. W. Iparraguirre (eds), Inclusión digital: Una mirada crítica sobre la evaluación del modelo uno a uno en Latinoamérica ('Digital inclusion: A critical view of the evaluation of the Uno a Uno model in Latin America'), Buenos Aires: Teseo, pp. 143-64, http://bit.ly/2WK10hn. Accessed 2 September 2019.

Dwyer, B. and Larson, L. (2014), 'The writer in the reader: Building communities of response in digital environments', in K. E. Pytash and R. E. Ferdig (eds), Exploring Technology for Writing and Writing Instruction, Hershey: IGI Global, pp. 202-20.

Fernandes, S., Mesquita, M., Flores, M. A. and Lima, R. M. (2014), 'Engaging students in learning: Findings from a study of project-led education', European Journal of Engineering Education, 39:1, pp. 55-67.

Galanouli, D., Murphy, C. and Gardner, J. (2004), 'Teachers' perceptions of the effectiveness of ICT-competence training', Computers \& Education, 43:1\&2, pp. 63-79.

Gibbes, M. and Carson, L. (2014), 'Project-based language learning: An activity theory analysis', Innovation in Language Learning and Teaching, 8:2, pp. 171-89.

Gilbert, D. (2016), 'Revitalizing music teacher preparation with selected Essential Conditions', Journal of Music, Technology and Education, 9:2, pp. 161-73.

Halvorsen, A. L., Duke, N. K., Brugar, K., Berka, M. and Brown, J. (2012), 'Narrowing the achievement gap in second-grade social studies and content area literacy: The promise of a project-based approach', working paper no. 26, East Lansing, MI: Education Policy Center, Michigan State University, https://files.eric.ed.gov/fulltext/ED537157.pdf. Accessed 20 September 2019.

Haning, M. (2016), 'Are they ready to teach with technology? An investigation of technology instruction in music teacher education programs', Journal of Music Teacher Education, 25:3, pp. 78-90.

Harris, J., Mishra, P. and Koehler, M. (2009), 'Teachers' technological pedagogical content knowledge and learning activity types: Curriculum-based technology integration refrained', Journal of Research on Technology in Education, 41:4, pp. 393-416. 
Harris, J., Phillips, M., Koehler, M. and Rosenberg, J. (2017), 'TPCK/TPACK research and development: Past, present and future directions', Australasian Journal of Educational Technology, 33:3, pp. i-viii.

Hassan, H., Domínguez, C., Martínez, J.-M., Perles, A., Albaladejo, J. and Capella, J.-V. (2008), 'Integrated multicourse project-based learning in electronic engineering', International Journal of Engineering Education, 24:3, pp. 581-91.

Helsper, E. and Eynon, R. (2010), 'Digital natives: Where is the evidence?', British Educational Research Journal, 36:3, pp. 503-20.

Hernández-Ramos, P. and De La Paz, S. (2009), 'Learning history in middle school by designing multimedia in a project-based learning experience', Journal of Research on Technology in Education, 42:2, pp. 151-73.

Herring, M., Koehler, M. and Mishra, P. (2016), Handbook of Technological Pedagogical Content Knowledge (TPACK) for Educators, 2nd ed., Oxon: Routledge, https://www.punyamishra.com/wp-content/uploads/2016/05/ Herring_et_al_2016.pdf . Accessed 23 September 2019.

Himonides, E. and Purves, R. (2010), 'The role of technology', in S. Hallam and A. Creech (eds), Music Education in the 21st Century in the United Kingdom: Achievements, Analysis and Aspirations, London: Institute of Education, https://www.researchgate.net/publication/244483669_The_role_of_technology. Accessed 24 August 2019.

Hsu, P. S., Van Dyke, M., Chen, Y. and Smith, T. J. (2015), 'The effect of a graphoriented computer-assisted project-based learning environment on argumentation skills', Journal of Computer Assisted Learning, 31:1, pp. 32-58.

Istenic, A., Cotic, M., Solomonides, I. and Volk, M. (2016), 'Engaging preservice primary and preprimary school teachers in digital storytelling for the teaching and learning of mathematics', British Journal of Educational Technology, 47:1, pp. 29-50.

Kirschner, P. A. and De Bruyckere, P. (2017), 'The myths of the digital native and the multitasker', Teaching and Teacher Education, 67, pp. 135-42.

Koehler, M., Mishra, P. and Cain, W. (2013), 'What is technological pedagogical content knowledge (TPACK)?', Journal of Education, 193:3, pp. 13-19.

Kokotsaki, D., Menzies, V. and Wiggins, A. (2016), 'Project-based learning: A review of the literature', Improving Schools, 19:3, pp. 267-77.

Larson, L., Forzani, E. and Leu, D. J. (2018), 'New literacies: Curricular implications', in J. Voogt, G. Knezek, R. Christensen and L. Kwok-Wing (eds), Second Handbook of Information Technology in Primary and Secondary Education, Cham: Springer International Publishing, pp. 38-52.

Lasauskiene, J. and Rauduvaite, A. (2015), 'Project-based learning at university: Teaching experiences of lecturers', Procedia-Social and Behavioral Sciences, 197, pp. 788-92.

Lee, J. S., Blackwell, S., Drake, J. and Moran, K. A. (2014), 'Taking a leap of faith: Redefining teaching and learning in higher education through project-based learning', Interdisciplinary Journal of Problem-Based Learning, 8:2, pp. 19-34.

Leman, M. and Nijs, L. (2016), 'Cognition and technology for instrumental music learning', in A. King, E. Himonides and A. Ruthmann (eds), The Routledge Companion to Music, Technology, and Education, Oxon: Routledge, pp. 23-35.

Ljung-Djärf, A., Magnusson, A. and Peterson, S. (2014), 'From doing to learning: Changed focus during a preschool learning study project on organic decomposition', International Journal of Science Education, 36:4, pp. 656-76. 
Lorenzo-Quiles, O., Vílchez-Fernández, N. and Herrera-Torres, L. (2015), 'Educational effectiveness analysis of the use of digital music learning objects: Comparison of digital versus non-digital teaching resources in compulsory secondary education', Infancia y Aprendizaje, 38:2, pp. 295-326.

Mettas, A. and Constantinou, C. P. (2008), 'The technology fair: A projectbased learning approach for enhancing problem solving skills and interest in design and technology education', International Journal of Technology and Design Education, 18:1, pp. 79-100.

Mioduser, D., Nachmias, R. and Forkosh-Baruch, A. (2008), 'New Literacies for the knowledge society', in J. Voogt and G. Knezek (eds), International Handbook of Information Technology in Primary and Secondary Education, Part One, New York: Springer, pp. 23-42, http://bit.ly/2JQJoIY. Accessed 2 October 2019.

Mishra, P. and Koehler, M. (2006), 'Technological pedagogical content knowledge: A framework for teacher knowledge', Teachers College Record, 108:6, pp. 1017-54, http://one2oneheights.pbworks.com/f/MISHRA_ PUNYA.pdf. Accessed 23 September 2019.

Mishra, P., Koehler, M. J. and Henriksen, D. (2010), 'The 7 transdisciplinary habits of mind: Extending the TPACK framework towards 21st century learning', Educational Technology, 51:2, pp. 22-28, http://bit.ly/2JSnCVa. Accessed 27 September 2019.

Mishra, P. and Mehta, R. (2017), 'What we educators get wrong about 21st-century learning: Results of a survey', Journal of Digital Learning in Teacher Education, 33:1, pp. 6-19.

Osborne, J. and Hennessy, S. (2003), Literature Review in Science Education and the Role of ICT: Promise, Problems and Future Directions, Bristol: Futurelab.

Pérez-Escoda, A. and Rodríguez Conde, M. J. (2016),'Evaluación de las competencias digitales autopercibidas del profesorado de educación primaria en Castilla y León' ('An evaluation of the self-perceived digital competences of primary education teachers in Castile and León'), Revista de Investigación Educativa, 34:2, pp. 399-415.

Pérez-Gil, M., Tejada, J., Morant, R. and Pérez, A. (2016), 'Cantus: Construction and evaluation of a software for real-time vocal music training and musical intonation assessment for music education', Journal of Music, Technology and Education, 9:2, pp. 125-44.

Prensky, M. (2001), 'Digital natives, digital immigrants part 1', On the Horizon, 9:5, pp. 1-6, http://bit.ly/2NHmhBK. Accessed 23 September 2019.

Sancho, J., Bosco, A., Alonso, C. and Sánchez, J. (2015), 'Formación del profesorado en Tecnología Educativa: de cómo las realidades generan los mitos' ('Teacher training in Educational Technology: How reality creates myth'), RELATEC: Revista Latinoamericana de Tecnología Educativa, 14:1, pp. 17-30.

Snow, K. (2004), 'What counts as literacy in early childhood?', in K. McCartney and D. Phillips (eds), Blackwell Handbook of Early Childhood Development, Malden, MA: Blackwell Publishing, pp. 274-94.

Somekh, B. (2008), 'Factors affecting teachers' pedagogical adoption of ICT', in J. Voogt and G. Knezek (eds), International Handbook of Information Technology in Primary and Secondary Education, New York: Springer, pp. 449-60.

Sweeney, T. and Drummond, A. (2013), 'How prepared are our pre-service teachers to integrate technology? A pilot study', Australian Educational Computing, 27, pp. 117-123, http://bit.ly/2PPu6rB. Accessed 2 October 2019. 
Thayer, T., Venegas-Thayer, A. and Tejada, J. (2019), 'Design, implementation and students' emotional assessment of a software for the learning of rational numbers through music metaphors in Chilean primary education: An exploratory study on audio fractions', International Journal of Innovation in Science and Mathematics Education, 27:2, pp. 1-17, https://bit.ly/audiofracciones. Accessed 24 August 2019.

Thompson, A. D. and Mishra, P. (2007), 'Breaking news: TPCK becomes TPACK!', Journal of Computing in Teacher Education, 24:2, pp. 38-64.

Venegas, A., Thayer, T. and Tejada, J. (2018), 'Recursos informáticos para el aprendizaje de las matemáticas mediante metáforas musicales: el proceso de creación y evaluación de PicaLab' ('Computer resources for learning mathematics through musical metaphors: The process of creating and evaluating PicaLab'), Estudios Pedagógicos, 44:1, pp. 351-76.

Vygotsky, L. (1979), El Desarrollo de los Procesos Psicológicos Superiores (Mind in Society: Development of Higher Psychological Processes), Barcelona: Austral.

Wilhelm, J., Sherrod, S. and Walters, K. (2008), 'Project-based learning environments: Challenging preservice teachers to act in the moment', The Journal of Educational Research, 101:4, pp. 220-33.

Zancul, E., Sousa-Zomer, T. and Cauchick-Miguel, P. (2017), 'Project-based learning approach: Improvements of an undergraduate course in new product development', Production, 27:spe, p. e20162252.

\section{SUGGESTED CITATION}

Tejada, Jesús and Morel, Tomás Thayer (2019),'Design and validation of a music technology course for initial music teacher education based on the TPACK framework and the project-based learning approach', Journal of Music, Technology \& Education, 12:3, pp. 225-246, doi: https://doi.org/10.1386/ jmte_00008_1

\section{CONTRIBUTOR DETAILS}

Jesús Tejada has a Ph.D. in research methods and diagnosis in education (University of Seville) and Ph.D. in humanities (University of La Rioja). Currently, he works as a senior lecturer and researcher at the Institute of Creativity and Educational Innovations of the University of Valencia, Spain.

Contact: Institut de Creativitat i Innovacions Educatives, Universitat de València, Serpis, 29, 46022 Valencia, Spain.

E-mail: jesus.tejada@uv.es

(1) https://orcid.org/0000-0003-0532-3960

Tomás Thayer Morel has a bachelor's degree in music and a master's degree in education majoring in education technology. He is currently a researcher and professor at the Department of Music of the Universidad Metropolitana de Ciencias de la Educación (UMCE). He is a doctoral candidate in the Specific Didactics doctoral programme at the Universitat de València.

Contact: Departamento de Música, Facultad de Artes y Educación Física, Universidad Metropolitana de Ciencias de la Educación, Av. José Pedro Alessandri 774, Ñuñoa, código postal 7760197 Santiago, Chile.

E-mail: tomas.thayer@umce.cl 
(10 https://orcid.org/0000-0003-3987-3952

Jesús Tejada and Tomás Thayer Morel have asserted their right under the Copyright, Designs and Patents Act, 1988, to be identified as the author of this work in the format that was submitted to Intellect Ltd. 